\title{
Insulin Micro-secretionin Patients with Long Duration Type 1 Diabetes: Implications of Interferon- $\gamma$ ?
}

\section{Raffaella Mormile*}

Division of Pediatrics and Neonatology, Moscati Hospital, Italy

*Corresponding author: Raffaella Mormile, Division of Pediatrics and Neonatology, Moscati Hospital-Via A. Gramsci, 3 81031 Aversa, Italy, Tel: +390815001503/+393392045468; E-mail: raffaellamormile@alice.it

Rec date: Apr 03, 2014, Acc date: May 13, 2014, Pub date: May 16, 2014

Copyright: () 2014 Mormile R. This is an open-access article distributed under the terms of the Creative Commons Attribution License, which permits unrestricted use, distribution, and reproduction in any medium, provided the original author and source are credited.

Type 1 diabetes (T1D) is a T-cell mediated autoimmune disease characterized by the destruction of pancreatic $\beta$-cells leading to absolute insulin deficiency [1]. Exogenous insulin represents the core of therapy for T1D that is fatal unless treated[2]. Several years of progressive autoimmune $\beta$-cells damage generally precede the clinical onset of diabetes [2]. Moreover, it has been found that the decline in insulin production in patients with T1D is variable [2]. The majority of patients with long-duration T1D has been demonstrated to be insulin microsecretors and to have residual functioning $\beta$-cells $[2,3]$. On this regard, it has been speculated that the small still functional $\beta$-cells could have escaped immune attack or have undergone a regeneration process known to be so far extremely limited in human adult $[2,4]$. Multiple immunological mechanisms have been proposed to contribute to $\beta$-cell destruction[5]. Although cytotoxic T lymphocytes directly attack $\beta$-cell in T1D, cytokines produced by immune system cells infiltrating pancreatic islets are candidate mediators of islet $\beta$-cell dysfunction and death [2-7]. Apoptosis represents the main form of cytokine-induced pancreatic $\beta$-cell death [5]. Different proinflammatory cytokines, such as Tumor necrosis factor- $\alpha$ (TNF- $\alpha$ ), Interleukin-1 (IL-1) and Interferon- $\gamma$ (IFN- $\gamma$ ), have been involved in T1D pathogenesis [1]. Among these cytokines, IFN- $\gamma$ has been conventionally described as responsible for driving pancreatic islets autoimmune damage, leading to $\beta$-cell apoptosis and the initial destruction of pancreatic $\beta$-cells in the onset of diabetes $[1,2,4-8]$. IFN$\gamma$ has been reported to influence immune and autoimmune responses by supporting the homing of diabetogenic activated $\mathrm{T}$ cells [8]. The development of diabetes has been linked to the accumulation of IFN- $\gamma$ producing T-cells in the islets [6]. Furthermore, an association between IFN- $\gamma$ polymorphism and T1D onset has been corroborated [7]. On the contrary, it has been provided evidence that IFN- $\gamma$ receptor deficiency prevents diabetes [9]. What is more, reduced diabetes incidence was observed by neutralizing endogenous IFN- $\gamma$ with anti IFN- $\gamma$ antibodies $[9,10]$. Interestingly, IFN $-\gamma$ has also been shown to play a major role in $\beta$-cell dysfunction associated with chronic pancreatitis [11]. The different biological effects of IFN- $\gamma$ have been connected with its action in regulating gene transcription $[5,7,12]$.

On this regard, it has been found that $\beta$-cells under attack are characterized by changes in their gene/protein expression that render them more vulnerable to the deadly effects of cytokines [5]. Janus family kinase 1 (JAK1)- signal transducer and activator of transcription 1(STAT1) signaling pathway are considered crucial transcription factors mediating the IFN- $\gamma$ effects on $\beta$-cell apoptosis and the subsequent development of T1D [3,5,12-14]. The JAK/STAT signaling cascade is an essential inflammatory signaling pathway that controls the immune responses [14]. It is a critical intracellular machinery of cytokines involved in gene expression and cellular activation, proliferation and differentiation $[12,13]$. IFN- $\gamma$ has been found to activate the expression of target genes through binding of activated STAT1 proteins on a consensus element termed the IFN- $\gamma$ activated site (GAS) $[15,16]$. It has been shown that upon stimulation of IFN- $\gamma$, JAKs are activated and phosphorylate STAT1that shapes a homodimer and moves into the nucleus binding to GASs within promoters of target gene $[5,15,16]$. Intriguingly, it has been reported that IFN- $\gamma$ is a transcriptional inducer of survivin gene in an autocrine manner through STAT1 pathway [16]. It has been detected that IFN$\gamma$-activated STAT1 binds directly to a GAS element in the survivin promoter region to trigger survivin expression [16]. Survivin is the smallest member of the inhibitor of apoptosis protein gene family [15-18]. It is an established cancer gene that is over-expressed in almost all human tumors and during embryonic and fetal development, whereas it is hardly detectable or minimally expressed in normal mature tissues $[15,17,18]$. It has been demonstrated that survivin orchestrates integrated cellular networks that are essential for tumour cell proliferation and viability [18]. Survivin has been implicated in cell death, cell division and cellular adaptation [15,17-19]. Initially, survivin has been shown to be expressed in $\beta$-cells of fetal human pancreas, but not in adult islets [17]. Recently, it has also been discovered in the $\beta$-cells in areas of pancreatitis and within lobular areas of surviving islets of pancreata of patients with presumed T1 childhood-onset diabetes [17-19]. Survivin has been involved in both the normal expansion of the $\beta$-cell mass after birth and in the survival of $\beta$-cells following stress-induced apoptosis [18-20]. Thus, survivin has been connected with the maintenance of $\beta$-cell mass via replication and anti-apoptotic mechanisms $[17,19,21]$. Concordantly, exogenous expression of survivin in a streptozotocin-induced model of diabetes has been correlated with protection of pancreatic $\beta$-cells from programmed cell death [22].

All these contentions led us to hypothesize that small still functional $\beta$-cells in long duration T1D undergo IFN- $\gamma$-mediated regeneration. We suggest that IFN- $\gamma$, via STAT1, has a dual and paradoxical role of inhibiting apoptosis preserving survival and expansion of islet $\beta$-cells through upregulation of survivin and concomitantly to promote apoptosis through JAK1 leading to $\beta$-cell death. Proteomic analysis should be directed toward increasing the understanding of the interplay among IFN- $\gamma$, JAK1/STAT1 and surviving in order to disclose novel molecules providing new therapeutic strategies employed to halt or even prevent T1D.Accurate evaluation of potential GAS sites in the survivin gene promoter able to bind STAT1 dimers is needed. Furthermore, clinical investigations are required to test the possibility to utilize selective JAK1 inhibitors to keep remaining $\beta$-cells from dying in children and young adults recently diagnosed with T1D. 
Citation: Mormile R (2014) Insulin Micro-secretionin Patients with Long Duration Type 1 Diabetes: Implications of Interferon-y?. J Diabetes

Page 2 of 2

\section{References}

1. Padgett LE, Broniowska KA, Hansen PA, Corbett JA, Tse HM (2013) The role of reactive oxygen species and proinflammatory cytokines in type 1 diabetes pathogenesis. Ann N Y Acad Sci 1281: 16-35.

2. Oram RA, Jones AG, Besser RE, Knight BA, Shields BM, et al. (2014) The majority of patients with long-duration type 1 diabetes are insulin microsecretors and have functioning beta cells. Diabetologia 57: 187-191.

3. Hassan GA, Sliem HA, Ellethy AT, Salama Mel-S (2012) Role of immune system modulation in prevention of type 1 diabetes mellitus. Indian J EndocrinolMetab 16: 904-909.

4. Meier JJ, Butler AE, Saisho Y, Monchamp T, Galasso R, et al. (2008) Betacell replication is the primary mechanism subserving the postnatal expansion of beta-cell mass in humans. Diabetes 57: 1584-1594.

5. Gysemans C, Callewaert H, Overbergh L, Mathieu C (2008) Cytokine signalling in the beta-cell: a dual role for IFN gamma. BiochemSoc Trans 36: 328-333.

6. Ablamunits V, Elias D, Reshef T, Cohen IR (1998) Islet T cells secreting IFN-gamma in NOD mouse diabetes: arrest by p277 peptide treatment. J Autoimmun 11: 73-81.

7. Rafinejad A, Niknam MH, Armirzargar AA, Khosravi F et al. 2004 Association of IFN-? gene polymorphos with Type 1 Diabetes in Iranian patients. IJI 2: 130-132.

8. Savinov AY, Wong FS, Chervonsky AV (2001) IFN-gamma affects homing of diabetogenic T cells. J Immunol 167: 6637-6643.

9. Nicoletti F, Zaccone P, Di Marco R, Lunetta M, Magro G, et al. (1997) Prevention of spontaneous autoimmune diabetes in diabetes-prone BB rats by prophylactic treatment with antirat interferon-gamma antibody. Endocrinology 138: 281-288.

10. Yi Z, Li L, Garland A, He Q, Wang H, et al. (2012) IFN- $\hat{\mathrm{I}}^{3}$ receptor deficiency prevents diabetes induction by diabetogenic CD4+, but not CD8+, T cells. Eur J Immunol 42: 2010-2018.

11. Pavan Kumar P, Radhika G, Rao GV, Pradeep R, Subramanyam C, et al. (2012) Interferon $\hat{\mathrm{I}}^{3}$ and glycemic status in diabetes associated with chronic pancreatitis. Pancreatology 12: 65-70.
12. Couto FM, Minn AH, Pise-Masison CA, Radonovich M, Brady JN, et al. (2007) Exenatide blocks JAK1-STAT1 in pancreatic beta cells Metabolism 56: 915-918

13. Moore F, Naamane N, Colli ML, Bouckenooghe T, Ortis F, et al. (2011) STAT1 is a master regulator of pancreatic \{beta\}-cell apoptosis and islet inflammation. J Biol Chem 286: 929-941.

14. Sun Q, Xiang RL, Yang YL, Feng K, Zhang K, et al. (2013) Suppressor of cytokine signaling 1 protects rat pancreatic islets from cytokine-induced apoptosis through Janus kinase/signal transducers and activators of transcription pathway. Chin Med J (Engl) 126: 4048-4053.

15. Darnell JE Jr, Kerr IM, Stark GR (1994) Jak-STAT pathways and transcriptional activation in response to IFNs and other extracellular signaling proteins. Science 264: 1415-1421.

16. Zimmerman M, Yang D, Hu X, Liu F, Singh N, et al. (2010) IFN- $\hat{I}^{3}$ upregulates survivin and Ifi202 expression to induce survival and proliferation of tumor-specific T cells. PLoS One 5: e14076.

17. Wu X, Zhang Q, Wang X, Zhu J, Xu K, et al. (2012) Survivin is required for beta-cell mass expansion in the pancreatic duct-ligated mouse model. PLoS One 7: e41976.

18. Altieri DC (2008) Survivin, cancer networks and pathway-directed drug discovery. Nat Rev Cancer 8: 61-70.

19. Jiang Y, Nishimura W, Devor-Henneman D, Kusewitt D, Wang H, et al. (2008) Postnatal expansion of the pancreatic beta-cell mass is dependent on survivin. Diabetes 57: 2718-2727.

20. Altieri DC (2008) Survivin, cancer networks and pathway-directed drug discovery. Nat Rev Cancer 8: 61-70.

21. Gianani R, Campbell-Thompson M, Sarkar SA, Wasserfall C, Pugliese A, et al. (2010) Dimorphic histopathology of long-standing childhood-onset diabetes. Diabetologia 53: 690-698.

22. Dohi T, Salz W, Costa M, Ariyan C, Basadonna GP, et al. (2006) Inhibition of apoptosis by survivin improves transplantation of pancreatic islets for treatment of diabetes in mice. EMBO Rep 7: 438-443. 